\title{
Variability of megathrust earthquakes in the world revealed by the 2011 Tohoku-oki Earthquake
}

\author{
Junji Koyama, Kazunori Yoshizawa, Kiyoshi Yomogida, and Motohiro Tsuzuki \\ Earth and Planetary Dynamics, Graduate School of Science, Hokkaido University, Sapporo 060-0810, Japan
}

(Received January 10, 2012; Revised April 10, 2012; Accepted April 27, 2012; Online published January 28, 2013)

\begin{abstract}
The seismicity of the Pacific coast of Tohoku, Japan, has been investigated in detail and characterized into regional seismic segments. The 2011 megathrust earthquake of $M_{\mathrm{w}} 9.0$ on 11 March ruptured almost all of the segments in that area, causing devastating tsunamis. The prime factor that had not been recognized before is the double segmentation along the Japan trench: The apparent absence of earthquakes in the trench-ward segments as opposed to the Japan Island-ward segments that have repeated smaller earthquakes. We term this pattern of seismic activity 'along-dip double segmentation (ADDS)'. The 2011 Tohoku megathrust earthquake is typical of a class of great earthquakes different from that of the 1960 Chile earthquake, in which a young and buoyant plate is subducting rapidly under the continental plate. In the 1960 Chile case, the seismic activity is characterized by 'along-strike single segmentation (ASSS)', where there is weak seismic activity before the main event all over the plate interface of the subduction zone. We study the greatest earthquakes around the world and find that there is a variety of megathrust earthquakes characterized by ASSS to ADDS, where the 2004 Sumatra-Andaman, the 1960 Chile, the 1964 Alaska and the 2011 Tohoku-oki earthquakes are typical end-members.
\end{abstract}

Key words: Megathrust earthquake, along-dip double segmentation, along-strike single segmentation, 2011 Tohoku, 1964 Alaska, 1960 Chile, 2004 Sumatra-Andaman, multiple segments.

\section{Introduction}

A megathrust earthquake of magnitude $\left(M_{\mathrm{w}}\right) 9.0$ occurred off the Pacific coast of Tohoku, Japan, on 11 March, 2011. This resulted in devastating tsunamis larger than any recorded in this area during the past 1,000 years. Based on past and present seismic activity, earthquakes off the Pacific coast of the Tohoku district had been extensively investigated and characterized as occurring on regional seismic segments. These seismic segments have been generally identified as the aftershock region of largest historical earthquakes there. The segmentation is also identified in Japan and its vicinity on the basis of transverse geologic and bathymetric structures on the underthrust and overriding plates (Ando, 1975), where repeated occurrences of large historical earthquakes are known within a particular single segment, or multiple segments. The geometric boundaries segmenting each seismic activity may be subducted sea mounts or ridges, and the deformation and curvature of trenches.

Official earthquake forecasting of Japan estimated a probability of $99 \%$ within 30 years of an earthquake of magnitude about 7.5 in the off Miyagi seismic segment, Tohoku, where the hypocenter of the 2011 megathrust earthquake was located. The 2011 megathrust earthquake ruptured almost all of the seismic segments between the Pacific coast of the Tohoku district and the Japan trench. Contiguous

Copyright (C) The Society of Geomagnetism and Earth, Planetary and Space Sciences (SGEPSS); The Seismological Society of Japan; The Volcanological Society of Japan; The Geodetic Society of Japan; The Japanese Society for Planetary Sciences; TERRAPUB.

doi:10.5047/eps.2012.04.011 segments of the fault spanning more than $500 \mathrm{~km}$ broke at once in the earthquake, rather than one or at most two, as had been anticipated. How did this event grow to such a scale?

As has been pointed out previously (Yomogida et al., 2011), a prime factor that had not been recognized before is the along-dip double segmentation along the Japan trench, due to the distinction between shallow and deep seismic segments perpendicular to the trench axis, and their successive ruptures induced by the strong initial break of the trench-ward segments. The double segmentation in the Tohoku district is due to the apparent absence of earthquakes, historically, in the trench-ward segments, in contrast to the smaller (up to $M_{\mathrm{w}} 7.5$ ) earthquakes that repeatedly break the deeper, Japan Island-ward segments.

Since we are not able to study the mechanical and dynamical characteristics of a particular plate-interface in detail, we have undertaken a comparative study of megathrust earthquakes in subduction zones of different ages and different tectonic settings. We investigate the focal process of the 2011 megathrust earthquake by comparing it with the greatest earthquakes which are known to have occurred in the world, considering characteristics such as earthquake activity, focal mechanisms, rupture patterns, geometry of subduction zones, types of overriding plates, and back-arc activity.

\section{The 2011 Tohoku-oki Megathrust Earthquake}

The seismic activity off the Pacific coast of the Tohoku district has been extensively investigated and characterized into regional seismic segments (Fig. 1). With the seg- 

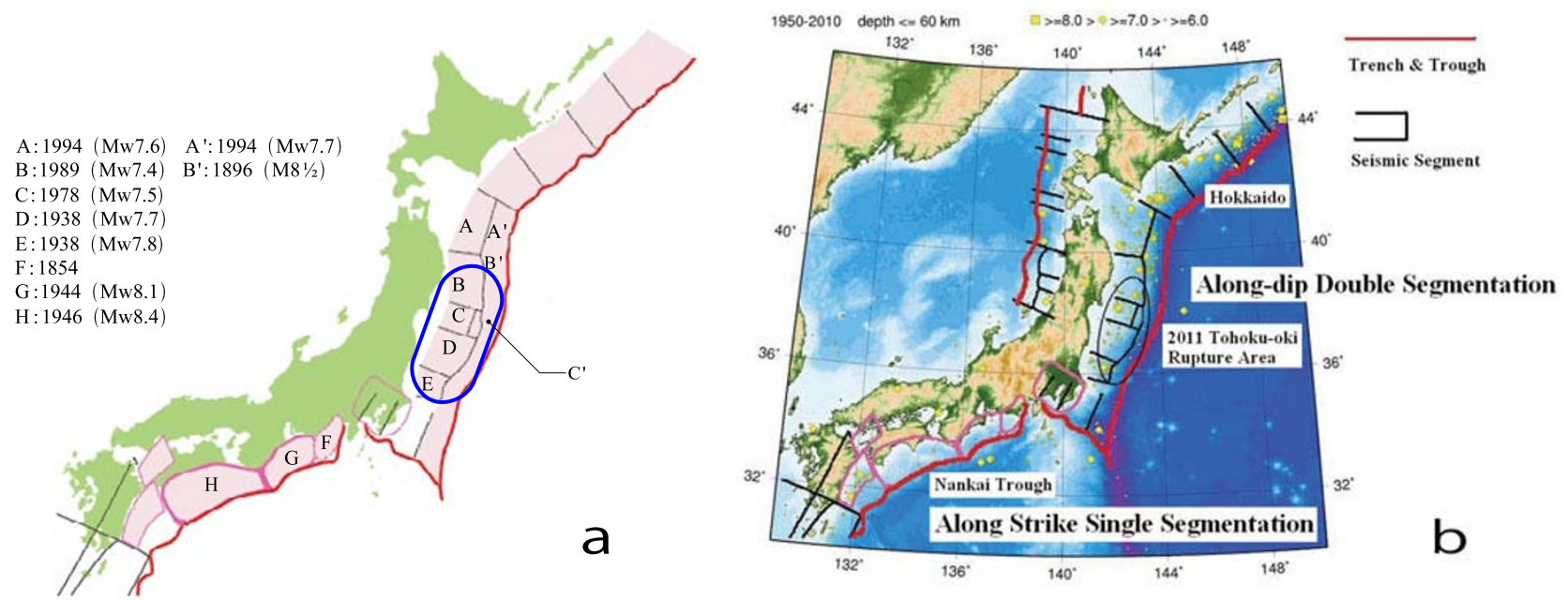

Fig. 1. Seismic activity in Japan and its vicinity. a: Seismic segmentation used in the official earthquake forecasting ${ }^{4}$ of the Evaluation of Major Subduction Zone Earthquakes by the Headquarters for Earthquake Research Promotion. The historically largest earthquake in each segment is indicated. b: Epicenters of earthquakes (yellow symbols classified by magnitude) from 1950 to 2010 with magnitudes given by Japan Meteorological Agency equal to, or larger than, 6.0 and focal depths equal to, or shallower than, $60 \mathrm{~km}$. Trenches and troughs near Japan are illustrated by red curves. The 2011 Tohoku-oki megathrust earthquake ruptured the area circled by the solid ellipse, where along-dip double segmentation (ADDS) is obvious. Along-strike single segmentation (ASSS) can be found in the Nankai Trough, where little recent seismic activity has been observed. Such regions are often called seismic gaps. ${ }^{4}$ http://www.j-shis.bosai.go.jp/map/?lang=en (2010).

ments being situated in one of the most intensively studied areas of the ongoing earthquake prediction project of Japan $^{1}$, the seismicity and the maximum size of the earthquakes in each segment have provided important information used to estimate the probability of future large earthquakes occurring there. All the earthquakes larger than $M_{\mathrm{w}} 8.0$ which have occurred over the last 150 years have been well-documented and investigated, and dense seismic monitoring systems have been in place for over 50 years. For example, the probability of a future $M_{\mathrm{w}} 7.5$ earthquake (or a slightly larger event) in Region C (hereafter Segment C) in Fig. 1(a), within the next 30 years, had been estimated to be as high as $99 \%$. Although a seismic scenario was proposed in which an earthquake ruptures Segment C initially and extends further towards the Japan trench in the east (Kawasaki et al., 2001), no probability of such an occurrence was estimated. Unfortunately, the 2011 megathrust earthquake was not confined to Segment C, as had been anticipated.

The map in Fig. 1(b) shows a series of segments with many earthquakes along the island arc of Japan. Seismicity in Segments $\mathrm{A}$ and $\mathrm{C}$ is particularly high, including several earthquakes as large as $M_{\mathrm{w}} 8$ in Segment $\mathrm{A}$ within the last 150 -year record. In contrast, seismic activity in Segments $\mathrm{D}$ and $\mathrm{E}$ was low, with no earthquakes larger than $M_{\mathrm{w}} 7.8$. Therefore, the 30-year probability of an $M_{\mathrm{w}} 7.4$ event in Segment D was judged to be less than 7\%. In Segment E, an earthquake smaller than $M_{\mathrm{w}} 7.0$ is expected with a probability of about $90 \%$. Although the plot of Fig. 1(b) uses a limited data set from 1950 to 2010, the general pattern of the seismicity is identical to the classical plots by Utsu (2001) who used the data sets of the International Seismological Center and the Japan Meteorological Agency. This drastic difference in seismic activity between two adjacent

\footnotetext{
${ }^{1}$ http://www.jisin.go.jp/main/index-e.html (2010).
}

segments (e.g., Segments C and D) is explained by interplate coupling in the north and decoupling in the south (Kanamori, 1977).

In addition, a long and narrow segment along the Japan trench has been recognized at a shallow depth on the $\mathrm{Pa}$ cific plate in Fig. 1(b). We name these segments $\mathrm{A}^{\prime}, \mathrm{B}^{\prime}$, and $\mathrm{C}^{\prime}$, respectively, corresponding to Segments $\mathrm{A}, \mathrm{B}$ and C. An area of slow slip after the 1994 earthquake $\left(M_{\mathrm{w}} 7.7\right)$ in Segment A extended to Segment A' (Heki et al., 1997). A large slow earthquake occurred in 1896 on Segment B', giving rise to a large tsunami that struck the eastern coast of northern Tohoku, causing more than 26,000 casualties (Kanamori, 1972; Usami, 1996). Since this slow earthquake generated weak seismic waves but gave rise to a devastating tsunami, this event was one of the largest tsunami earthquakes in over 1000 years in Japan. Recent earthquakes in $1989\left(M_{\mathrm{w}} 7.4\right)$ and $1992\left(M_{\mathrm{w}} 6.9\right)$ occurred in Segment B and extended into Segment B' as postseismic slow slips (Kawasaki et al., 2001). Slow slips and slow earthquakes in Segments $\mathrm{A}^{\prime}$ and $\mathrm{B}^{\prime}$ released about $30 \%$ of the interseismic stress accumulation (Heki et al., 1997; Kawasaki et al., 2001). The rest of the $70 \%$ deficit is considered to be relaxed by aseismic slips along the subduction zone, or accounted for by some unknown stress accumulation which has been in effect for more than 1000 years (Kanamori et al., 2006). Seismic activity of large earthquakes within Segments B and B', as well as all the segments at a shallow depth along the Japan trench, has been, however, extremely low. Thus, there has been no probability estimate for a future large earthquake there. Although a future earthquake on the multiple Segments B' and $\mathrm{C}^{\prime}$ has been estimated possibly to grow as large as $M_{\mathrm{w}} 8$ (Tanioka and Satake, 1996), there has been no evidence to infer such an occurrence. The point is that it has been believed that there is a double seismic segmentation along the Japan Trench, as in Fig. 1, and that the segments 
along the island-arc side of Japan frequently generate earthquakes as large as $M_{\mathrm{w}} 8$ but the segments along the Japan Trench rupture aseismically. Hereafter, we call this type of peculiar seismic segmentation as along-dip double segmentation (ADDS). Unfortunately, the 2011 megathrust earthquake extended across all these segments, covering an area of about $200 \times 500 \mathrm{~km}^{2}$, as in Fig. 1 .

Thus, the question is why and how the rupture extended southward into both seismically-inactive Segments D and $\mathrm{E}$, and also the shallow trench-ward segments of the subduction zone, resulting in the unexpected devastating occurrence of the 2011 megathrust earthquake. One possible scenario is that the initial rupture in Segment $C$ was accompanied by a rupture in the adjacent trench-ward Segment $\mathrm{C}^{\prime}$, where these two segments had been believed to be activated independently if they were ruptured. This combined initial rupture could have been strong enough to produce a stress concentration to overcome any existing strong areas (called barriers) to adjacent segments. We believe that the 2011 megathrust earthquake was not a conventional great earthquake, which had been thought to be confined only to multiple Segments B, C, D and E in the island-arc direction. Instead, there occurred the 2011 megathrust event of these segments that also involved trench-ward shallow segments. Reports on tsunami excitation (Maeda et al., 2011) and seismic waveform inversions of teleseismic and strong motion data (Koketsu et al., 2011; Yoshida et al., 2011) revealed a large fault slip in Segments $\mathrm{B}^{\prime}$ and $\mathrm{C}^{\prime}$, supporting the scenario of our strong initial rupture. The lack of strong seismic directivity in the excitation of long-period surface waves (Ide et al., 2011; Yomogida et al., 2011) also supports the contention that the majority of the seismic moment release was concentrated in the initial break of the hypocentral area.

The best-known typical megathrust earthquake in Japan is the 1707 Houei great earthquake along the Nankai trough (multiple-segment rupture of Segments F, G and $\mathrm{H}$ of Fig. 1(a)). This classical example exhibits a clear lateral (i.e., along the trench-axis direction) interaction between adjacent segments. However, even given our hypothesis for the 2011 megathrust event, we acknowledge that the 2011 event is not the same as the classical 1707 great earthquake, where little seismicity was observed, neither in the land-ward nor the trench-ward areas (Fig. 1(b)). The inactive seismicity in this region not only applies to the period analyzed in Fig. 1(b), but also to the period from 1924 to the present, according to the Japan Meteorological Agency data ${ }^{2}$ except for the activity following the 1944 Tonankai earthquake in Segment G of Fig. 1(a) and the 1946 Nankaido earthquake in Segment H. Therefore, Segments $\mathrm{G}$ and $\mathrm{H}$ are also identified as a seismic gap as well as Segment F, which can be found in Fig. 1(b). This type of multiple-segment great earthquake is referred as an earthquake of along-strike single segmentation (ASSS) in contrast to ADDS of the 2011 Tohoku-oki megathrust event. The difference between these two types of segmentations is that strongly-coupled areas of trench-ward segments give rise to ADDS, whereas almost $100 \%$ coupled areas of shal-

\footnotetext{
${ }^{2}$ http://www.jma.go.jp/jma/en/Activities/earthquake.html.
}

low parts of the subduction zone give rise to ASSS. In other words, any seismic gap can be identified for ASSS earthquakes, while there occurs a doughnut pattern of seismicity prior to large ADDS earthquakes (Kelleher and Savino, 1975). To support this argument, we consider recent and well-studied great earthquakes around the world, comparing them with the 2011 megathrust earthquake and the 1707 Houei great earthquake.

\section{The 1960 Chile Earthquake and the 1964 Alaska Earthquake}

The 1960 Chile $\left(M_{\mathrm{w}} 9.5\right)$ and 2010 Maule, Chile $\left(M_{\mathrm{w}} 8.8\right)$, earthquakes are similar in type to the 1707 Houei great earthquake. Cisternas et al. (2005) investigated the tsunami deposit along the coast of Chile and suggested that the fault rupture of the 1960 earthquake spanned two to three seismic segments along the trench. The 2010 Maule earthquake ruptured seismic segments that broke in the 1835 Concepcion $\left(M\right.$ 8.2) and 1928 Talca $\left(M_{\mathrm{s}} 8.0\right)$ earthquakes (Comte and Beck, 2010). Figure 2 shows a spacetime plot of seismic activity along the Peru-Chile trench from January 1900 to July 2011. Seismic activity preceding the 1960 and 2010 great earthquakes was very low over the entire aftershock areas, suggesting almost $100 \%$ coupling along the subduction zone. This evidence implies that there were seismic gaps, regions of very low seismic activity, along the trench prior to these greatest earthquakes, and these gaps ruptured releasing large seismic moments. Moreno et al. (2010) showed the similarity between coseismic slips on the fault in the 2010 Maule earthquake, and the interseismic locked patches (seismic gaps) before the earthquake shown by GPS observation along the coast line of Chile-Peru. Thus, seismic activity along the Chile trench, as at the Nankai trough (Fig. 1(b)), is characterized by ASSS, in contrast to ADDS observed for the 2011 megathrust earthquake.

Another similarity between the 1960 Chile earthquake and the Nankai trough (the 1707 Houei ruptured area) is the occurrence of slow-slip events in the deeper part of the seismically-coupled area. Slow slip was observed prior to the 1960 Chile by Kanamori and Ciper (1974), and numerous slow-slip events occur at the Nankai trough (Obara, 2002). In the Cascade subduction zone in Canada, the Geological Survey of Canada has found episodic tremor and slip $(\mathrm{ETS})^{3}$ in the deeper part of the locked patch that is quite similar to slow-slip events in the Nankai trough. Slow slips in the deeper part of coupled areas along subduction zones would be a common feature for the subduction of young, and warmer, oceanic crust, which has been classified by Uyeda and Kanamori (1979) as Chilean-type subduction. The strong coupling of the subduction zone would produce a dominant compression over the overriding plate, high uplift rates of the continental arc, which is known as Cordilleran orogeny, and a well-developed accretion complex in the shallow trench (Uyeda, 1982).

In contrast to the 1960 Chile earthquake, seismic activity before, and after, the 1964 Alaska earthquake was more-orless similar to the ADDS associated with the 2011 Tohoku-

\footnotetext{
${ }^{3}$ http://gsc.nrcan.gc.ca/geodyn/silentslip_e.php.
} 


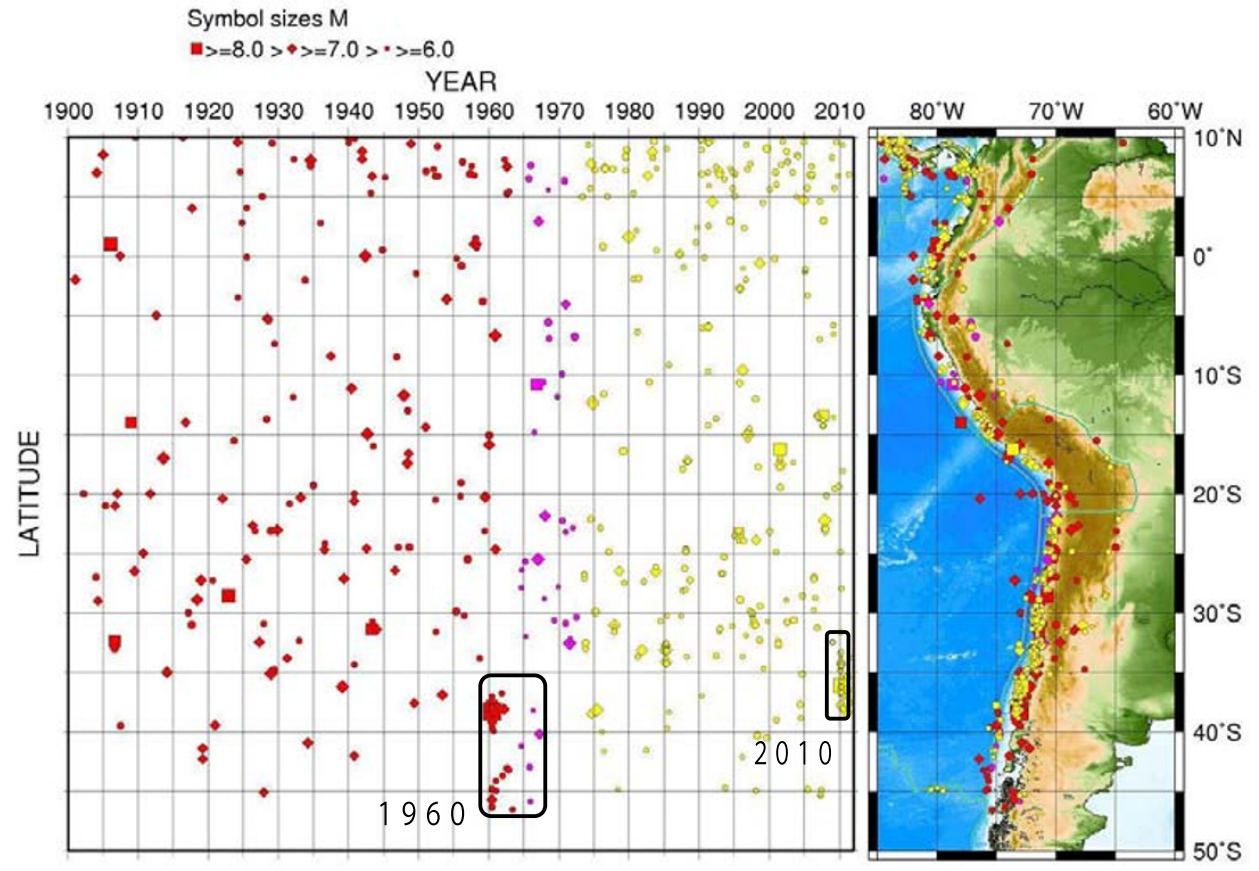

Fig. 2. Seismic activity along the Chilean subduction zone. We notice sparse seismicity prior to the 1960 and 2010 great earthquakes (seismic gap) and a narrow seismically active area along the subduction zone. These are typical characteristics of ASSS. Epicenters relocated by Engdahl et al. (1998) are used from 1900 to 1972. From 1973 to July 2011, the USGS NEIC database ${ }^{5}$ has been analyzed. ${ }^{5}$ http://earthquake.usgs.gov/earthquakes/eqarchives/epic/epic_global.php.
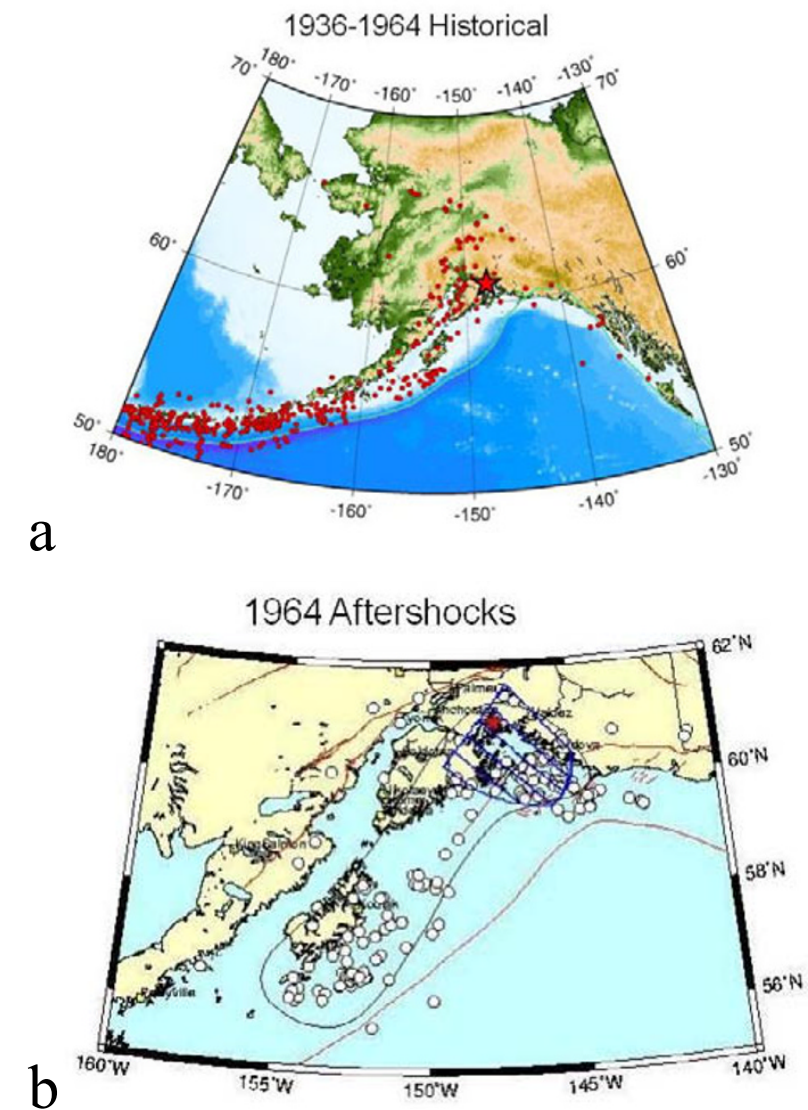

Fig. 3. Seismic activity prior to, and after, the 1964 Alaska earthquake (reproduced from Yomogida et al., 2011). Historical earthquakes from 1936 to before the 1964 Alaska earthquake of magnitudes equal to, or larger than, 5.0, and focal depths equal to, or shallower than, $60 \mathrm{~km}$ are plotted on the top. Aftershocks on the bottom are from the Alaska Earthquake Information Center ${ }^{6}$, and the asperity from Ruff and Kanamori (1983) is indicated by the shaded area. ${ }^{6}$ http://www.aeic.alaska.edu/quakes/Alaska_1964_earthquake.html. 
oki megathrust (Fig. 3). There were no prior earthquakes in the trench-ward region of the aftershock area of the 1964 Alaska earthquake, but strong activity in the hypocentral area in the land-ward region could be found before the earthquake. Two asperities of the 1964 Alaska earthquake where there are areas of large seismic moment release compared to the surroundings and which are considered to be areas of strongly-coupled plate interface were known as the Prince William Sound (PWS) asperity and the Kodiak asperity (e.g., Doser et al., 2006), respectively, to the eastern and western parts of the aftershock area. Aftershocks spread over the area, including the two asperities, implying that the seismic segment is not necessarily the same as the asperity but, rather, a spatial extent of the aftershock areas, including an asperity and its surrounding. The PWS asperity is limited in space as in Fig. 3 (Ruff and Kanamori, 1983), extending to the trench axis from the hypocenter. Although the aftershock activity in and around the Kodiak asperity can also be found in Fig. 3, the seismic moment release of the Kodiak asperity was much smaller than that of the PWS asperity (Johnson et al., 1996; Doser et al., 2006). These are consistent with the strong initial break (Wyss and Brune, 1967) of the 1964 Alaska earthquake and the ADDS type of rupture patterns similar to the 2011 megathrust, which can be clearly distinguished from the 1707, 1960 and 2010 earthquakes.

The fault geometries of the 1964 Alaska and 2011 Tohoku-oki megathrust earthquakes are very wide with a ratio of fault width to length of $1: 2 \sim 3$, whereas that for the 1960 Chile earthquake is about $1: 5$. Seismic absence along the Chile trench and the Nankai trough implies the smooth and strongly-coupled zone along the subduction. Recent GPS observations by Freymueller et al. (2008) and seismic moment release along the rupture zone of the 1964 Alaska earthquake (Doser et al., 2006) reveal a strong variability along the strike of the Alaska and the Aleutian arc. These are the similarities between the 1964 Alaska and 2011 Tohoku-oki megathrusts, the latter of which was discussed in Section 2. We note, however, that the overriding plate in Alaska is continental, forming the Alaskan range, while in Tohoku it is the Japan Islands continental margin with the back-arc basin. There seems to be a strong difference in overriding plates between Alaska and Tohoku, the stress fields in both regions are compressional (Uyeda, 1982; Freymueller et al., 2008), which leads to thrust faultings along subduction zones and consequently gives rise to the Pacific-type orogeny (Maruyama, 1997) to the latter.

\section{The 2004 Sumatra Earthquake and the $\mathbf{1 9 6 5}$} Rat Island Earthquake: Oblique Subductions

Megathrust earthquakes had been believed to occur only in so-called Chilean-type subduction zones (e.g., Kanamori, 1977; Lay et al., 1982; Uyeda, 1982): The fault areas of Chilean-type megathrust earthquakes are very narrow, and the seismicity preceding these earthquakes is very weak. In addition, the oceanic plate subducts rapidly and almost orthogonally to the overriding continental plate. In contrast to the 1960 Chile earthquake, the 2004 Sumatra-Andaman earthquake $\left(M_{\mathrm{w}}\right.$ 9.3) (Stein and Okal, 2007) shows several peculiar characteristics. The first is that the earthquake occurred at the Sunda-Andaman trench, where the IndoAustralian plate subducts obliquely under the Burma-Sunda subplates: a continental margin. The second is that the event ruptured about $1300 \mathrm{~km}$ of a curved plate boundary along which the direction of the subduction changes (Lay et al., 2005). The third is that the source area is where the Burma subplate has been sheared off parallel to the subduction zone as a result of the highly-oblique motion of the IndoAustralia plate due to the back-arc activity. The back-arc tectonics of this area is controlled by the active Andaman Sea spreading center and the Sumatra/Sagaing transform system, which is the typical example of slip-partitioning tectonics (McCaffrey, 1992; Stein and Sella, 2002). The fourth is that this active back-arc activity compensates for the oblique motion of the Indo-Australian plate, leaving the predominantly low-angle thrust motion component observed in the 2004 Sumatra- Andaman earthquake (Lay et al., 2005; Stein and Okal, 2007).

Lay et al. (2005) showed the intense level of activity prior to the 2004 Sumatra-Andaman earthquake in the vicinity of the 2004 hypocenter and the comparatively low level of seismicity all the way to the terminus of the rupture zone of the event. Ammon et al. (2005) investigated not only the long-period, but also the short-period, energy release in the 2004 event, with a rapid increase in moment release and an accompanying burst of short-period energy from 50 to 200 seconds after the origin time of the event. The corresponding rupture region is the Sumatra segment including the hypocentral area (Lay et al., 2005), the region of the possible failure of a relatively strong section of the earthquake. These observations suggest that the initial breakage of the 2004 Sumatra-Andaman earthquake has some characteristics of ADDS. However, the successive multiple ruptures of narrow and long rupture zones of the event and the prior weak seismic activity suggest ASSS for the earthquake as a whole. The very long duration of the seismic moment release of the event (Ammon et al., 2005; Stein and Okal, 2007) suggests ASSS, whereas a large single pulse of moment release functions occurs for ADDS earthquakes, such as the 1964 Alaska (Ruff and Kanamori, 1983) and the 2011 Tohoku-oki (Ide et al., 2011; Shao et al., 2011) earthquakes in Fig. 4.

The 2004 Sumatra-Andaman earthquake is not the only case which occurred along a curved plate boundary with an obliquely subducting oceanic plate. There are found for the 1965 Rat Island earthquake $\left(M_{\mathrm{w}} 8.7\right)$, and the 1957 Andreanof earthquake $\left(M_{\mathrm{w}} 9.1\right)$, along the Aleutian trench. Figure 5 shows the focal mechanisms of recent large earthquakes in the Aleutian Islands, which indicates that rightlateral strike slip faultings occur in the Aleutian Islands, whereas low-angle thrust faultings occur along the subduction zone. These focal mechanisms show that a sliver block between the Aleutian trench and Aleutian Islands has sheared off parallel to the subduction zone due to the highly-oblique motion of the Pacific plate. The oblique motion is partitioned, yielding a low-angle thrust component orthogonal to the trench direction being the mechanism of earthquakes in the subduction zone (Fig. 5). GPS observations in the islands indicate the expected northwestward motion (Freymueller et al., 2008). These features of the 

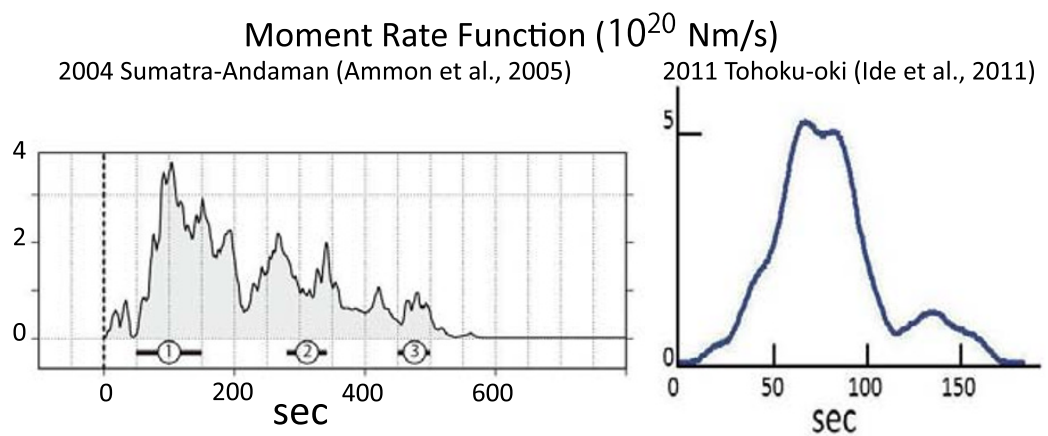

Fig. 4. Moment release time functions for the 2004 Sumatra-Andaman (Ammon et al., 2005) and 2011 Tohoku-oki (Ide et al., 2011 ) earthquakes. These are typical megathrust events for regions of ASSS and ADDS
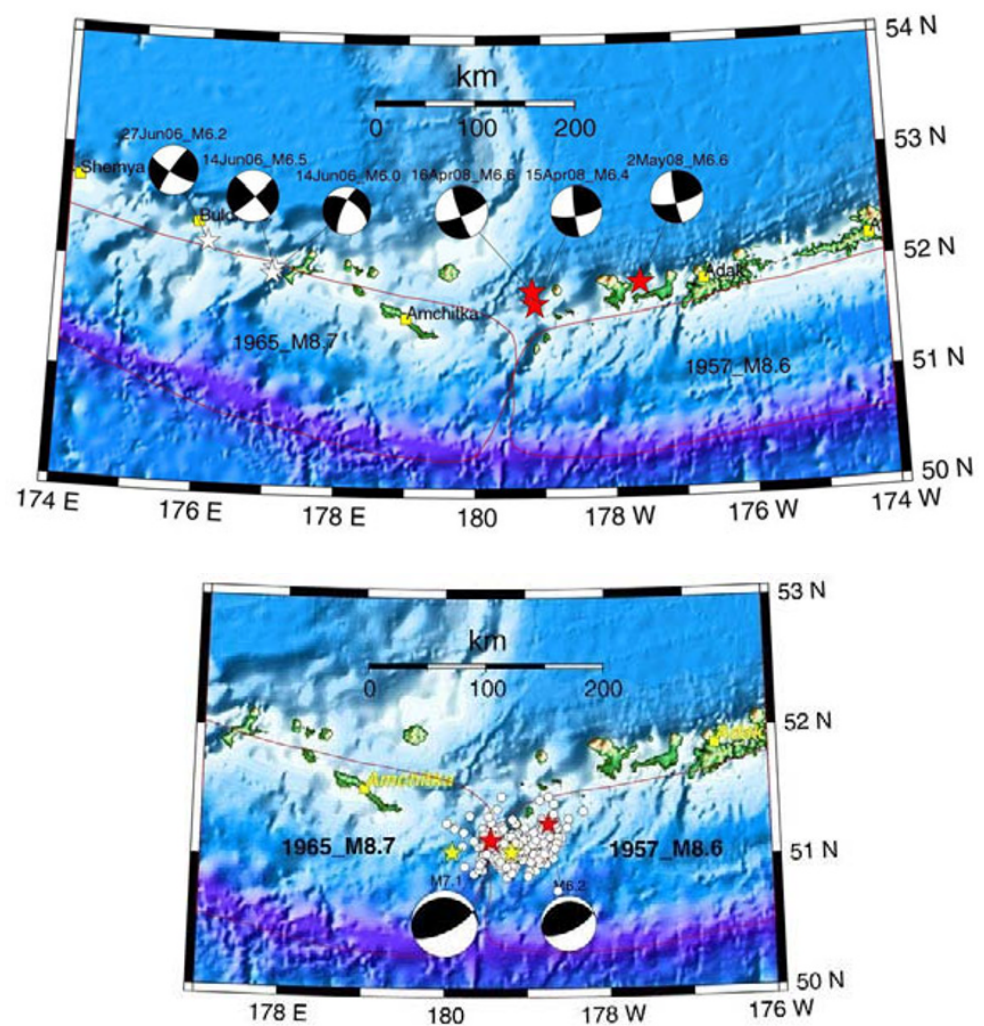

Fig. 5. Focal mechanism solutions of earthquakes in the Aleutian Islands. Top: major earthquakes with right-lateral strike slip from 2006 to 2008. Bottom: Major earthquakes in December, 2007 of low-angle thrust type with small strike-slip components in the subduction zone. Figures are from the same web site as in Fig. 3.

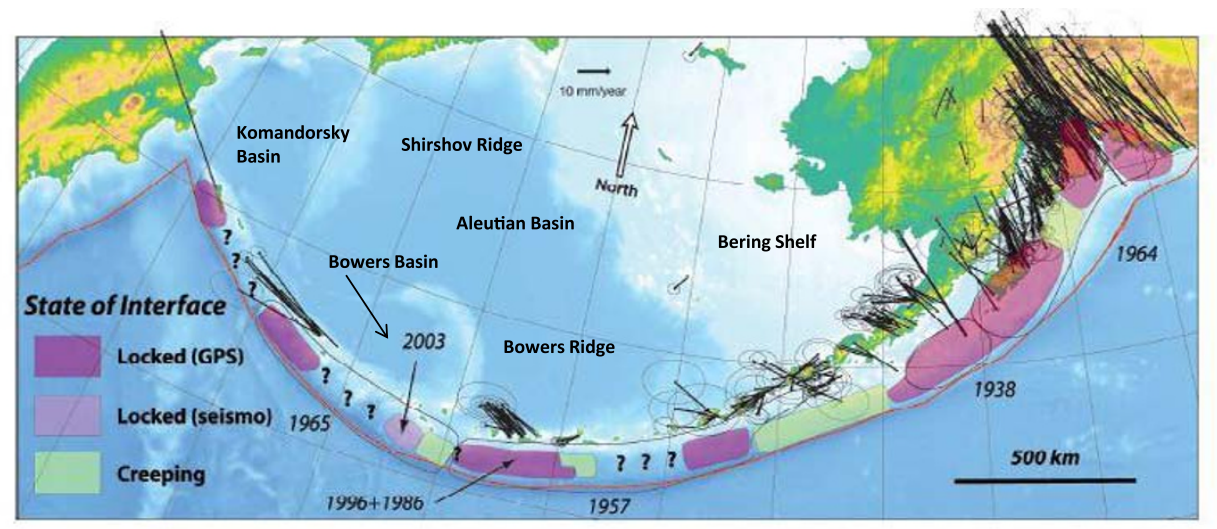

Fig. 6. GPS results and large earthquakes in the Alaska-Aleutian Islands. Reproduced from Freymueller et al. (2008) with slight modifications of the ocean topography. 
Table 1. Variability of megathrust earthquakes in the world.

\begin{tabular}{cccc}
\hline Event & Overriding Plate & Segmentation & Remarks \\
\hline 2004 Sumatra* & Continental Margin & Single & Oblique \\
\hline 1957 Andreanof & Continental Margin & Single & Oblique \\
\hline 1960 Rat Island & Continental Margin & Single & Oblique \\
\hline 1060 Chile & Continent & Single & Cordilleran Orogeny \\
\hline 2010 Chile & Continent & Single & Cordilleran Orogeny \\
\hline 1964 Alaska & Continent & Double & Cordilleran Orogeny \\
\hline 1952 Kamchatka & Continental Margin & Double & Cordilleran Orogeny \\
\hline 2011 Tohoku-oki & Continental Margin & Double & Pacific-type Orogeny \\
\hline
\end{tabular}

*Boldface indicates a typical end-member characterized by the category of single/double segmentation, orthogonal/oblique subduction and type of overriding plate/orogeny. ${ }^{7}$ : Uyeda (1982); ${ }^{8}$ : Maruyama (1997).

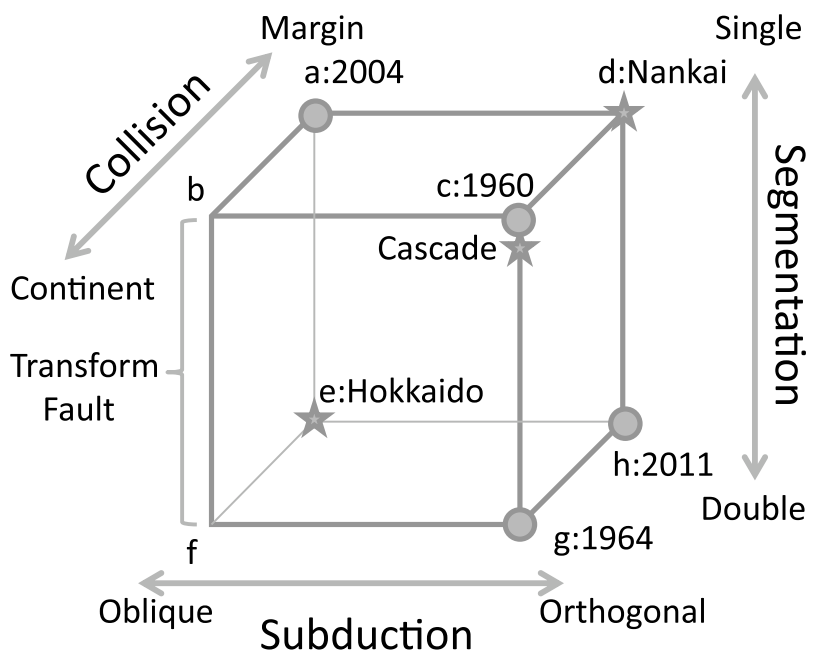

Fig. 7. Variability of megathrust earthquakes in terms of seismic segmentation (along-strike single segmentation, ASSS or along-dip double segmentation, ADDS), subduction zone geometry (orthogonal or oblique) and collision with continental plate or continental margin. Typical end-members of great earthquakes are plotted by solid circles with their year of occurrences. Possible future large earthquakes in Hokkaido and Nankai Trough (Fig. 1(b)) and the Cascade subduction zone are indicated by stars.

slip partitioning (Stein and Sella, 2002) are quite similar to those observed in the Andaman-Nicobar trench. However, the back-arc activity in the Aleutian Islands is not comparable with the active Andaman spreading center and the Sumatra/Sagaing fault. The curious Shirshov ridge and the Bowers ridge in the western part of the Bering Sea are inactive and aseismic with a lack of evidence of subduction (Neprochnov et al., 1985; Marlow et al., 1990). Figure 6 shows GPS results along the Alaska and Aleutian Islands and ocean-bottom topography (Freymueller et al., 2008). Note the dramatic along-strike variability of the Alaska/Aleutian subduction zone with large earthquakes, characterized by locked regions of significant slip deficit based on GPS data-locked regions inferred from seismic ruptures, and creeping segments. A similar lateral variability in rupture mode at individual trench segments is found in the Sumatra-Andaman subduction zone (Stein and Okal, 2007).

\section{Summary and Discussion}

The 2011 Tohoku-oki megathrust earthquake has significantly contributed to our knowledge about the greatest earthquakes. From studying the seismic activity and the tectonics of the earthquakes, we are able to identify various patterns relating to the characteristics of seismic activity, focal mechanisms, rupture patterns, geometry of subduction zones, the types of overriding plates, and back-arc activity. Table 1 summarizes seven recent great earthquakes and indicates this variability. The 2004 Sumatra-Andaman, 1960 Chile, 1964 Alaska, and 2011 Tohoku-oki, events are end-members, from a typical ASSS to an ADDS showing the variation in order. Figure 7 illustrates the characteristics of the megathrust earthquakes in terms of seismic segmentation (ASSS or ADDS), subduction geometry (oblique or orthogonal) and collision with continental plate or continental margin. The listed end-members are plotted by solid circles, and seismic regions where future large earthquakes are expected are plotted by stars. The Nankai trough is a typical example of ASSS, where a seismic gap has been observed, and the Hokkaido region is typical of ADDS (Fig. 1(b)). The Cascade subduction zone is classified, similarly to the 1960 Chile earthquake, as ASSS.

Recent GPS observations enable us to estimate slip deficits or plate couplings before the earthquakes occur. 
Moreno et al. (2010) showed a similarity between an interseismic locked patch and coseismic slip on the fault zone of the 2010 Maule earthquake, indicating that an almost $100 \%$ coupled-fault area arises in the case of an ASSS. The 2010 Maule earthquake is also identifed as a seismic-gap filling event (Moreno et al., 2010), which is characteristic of an ASSS. Ozawa et al. (2011) showed the distributions of the coseismic, and post-seismic, slip of the 2011 Tohoku-oki earthquake from the ground displacement detected by the GPS network in Japan, which matched the area of the preseismic locked zone of the event (Suwa et al., 2006). The area of the strongly-coupled zone in the Tohoku-oki region is restricted, suggesting the characteristics of ADDS, although the position of the preseismic locked zone by Suwa et al. (2006) is a little close to the Japan Islands and away from the central part of the coseismic slip in the event.

It seems strange that the focal mechanism of the 2004 Sumatra-Andaman earthquake is of the low-angle thrust type, where the Indo-Australia plate is subducting highly obliquely. Stein and Okal (2007) fully explained the reason, which is presented in Section 4. The body-wave fault plane solutions of the Rat Island earthquake and its aftershocks have been studied in detail by Stauder (1968), suggesting low-angle thrusting. Wu and Kanamori (1973) found that the radiation pattern of long-period surface waves of the Rat Island earthquake is consistent with Stauder's solutions, but with a considerable strike-slip component. Since then, many large earthquakes have occurred in the Rat-, and the Andreanof-, Island regions whose focal-mechanism solutions are either low-angle thrusting with a small amount of strike-slip component or the right-lateral strike-slip type as in Fig. 5. We could, therefore, conclude that the focal mechanism of great earthquakes along a curved plate boundary, where the subduction of the oceanic plate is highly oblique, would be low-angle thrust faulting. This idea would help us to understand future earthquakes along curved plate boundaries with oblique subduction.

Slow-slip events would be a general feature in the deeper part of ASSS. We note two slow earthquakes (Kawasaki et al., 2001) and the tsunami earthquake (Tanioka and Satake, 1996) at the northern terminus of the 2011 Tohoku-oki megathrust. The southern terminus of the rupture zone of the 2011 Tohoku-oki megathrust is thought to be a region of little seismic potential for large earthquakes. For the 1964 Alaska, it seems that the creeping zone (Fig. 6), next to the PWS asperity (Fig. 3), prevented the rupture propagation from a strong initial break (Wyss and Brune, 1967; Ruff and Kanamori, 1983), which may result in a seismic directivity of long-period surface waves unoriented to that of its aftershock region (Kanamori, 1970). Therefore, we propose that slow-slip events occur very close to the stronglycoupled zones due to the along-strike variability of subduction zones. However, this hypothesis needs further justification.

What we have found in this study is the variety of megathrust earthquakes associated with the rupture of multiple seismic segments, which are no longer confined to a single or double seismic segments. We need to consider both along-dip, and along-strike, rupture propagations for the possible occurrence of a megathrust earthquake. The along-dip variability of subduction zones can be understood by the evolution of sedimentary layers in its plate interface (Bilek and Lay, 1999). Although along-strike variability of subduction zones has been pointed out by GPS observations (e.g., Freymueller et al., 2008), characterized by various types of slow-seismic events (e.g., Obara, 2009) and classified by the lateral variation of sedimentary layers (e.g., Tsuru et al., 2002), there still remains the questions how the strong initial rupture occurs and how the rupture extends laterally along the strike direction overcoming any existing fault-resistant areas (called barriers) resulting in a multiplesegment rupture.

\section{Conclusion}

Important lessons from the 2011 megathrust earthquake can be summarized as follows:

(1) We should not construct a future large-earthquake scenario in a given region based solely on seismic activity recorded over a short period of time, such as less than 1,000 years. We should also consider short-term (geodetic/seismic), and long-term (geologic or relative plate velocity), observations on strain accumulations along the subduction zones. Although a seismic gap would indicate a possible future earthquake in regions of ASSS, such a gap would not be identified in regions of ADDS due to seismic activity on the land-ward side.

(2) The traditional one-dimensional segmentation scheme, of one subduction zone divided into a series of segments along the trench axis, does not apply in many cases. It would work for ASSS regions, such as is illustrated in Fig. 1. The 1960 Chile great earthquake that ruptured along-strike segments, one by one, where all the segments appear to be fully coupled beforehand. In contrast, for ADDS regions, the successive initial rupture of double segments in the deep and shallow parts of the subduction zone must be considered, which should induce secondary ruptures of surrounding segments.

(3) The successive initial rupture of the double segmentation, which turned out to be dominant in the 2011 megathrust earthquake, has been overlooked completely because of the successive lateral ruptures in the 1960 Chile and 2004 Sumatra earthquakes, as examples in the past. This wide range of variation in rupture behavior is likely to be caused by variations in the nature of subduction due to plate age, convergence rate, amount of accretion sediments, geometrical irregularities including seamounts, overriding plates and back-arc activity. Further new ideas are required with respect to their classifications, based not on the traditional one-dimensional scheme, but on a two-dimensional scheme incorporating the segmentations of seismic zones.

(4) The shallow segment of the subduction zone (Segment $\mathrm{C}^{\prime}$ in Fig. 1(a)) of the 2011 earthquake had been believed to be safe because of its sparse seismicity and the absence of historical records of large earthquakes. Slow earthquakes and slow slips were believed to be due to weak and soft materials at shallow depths near 
its trench axis. We must now recognize that such a shallow zone may cause large seismic slips, which can eventually lead to a megathrust earthquake.

(5) Looking only at seismicity near Japan, we find two types of segmentations, ASSS in the Nankai Trough and ADDS in Hokkaido (Fig. 1(b)). Therefore, we need to focus on these areas to learn more about the two different types of megathrust earthquakes that may occur in the near future.

Acknowledgments. We appreciate the help of Yosio Nakamura of the University of Texas for kindly reading the draft paper in the early stage of this study and helping us to improve the understanding of seismic segmentations. We are also grateful to S. Stein of Northwestern University for his critical reviews to improve and deepen the discussions of our manuscript.

\section{References}

Ammon, C. J., C. Ji, H.-K. Thio, D. Robson, S. Ni, V. Hjorleifsdottir, H. Kanamori, T. Lay, S. Das, D. Helmberger, G. Ichinose, J. Polet, and D. Wald, Rupture process of the 2004 Sumatra-Andaman earthquake, Science, 308, 1133-1139, 2005.

Ando, M., Source mechanisms and tectonic significance of historical earthquakes along the Nankai trough, Japan, Tectonophysics, 27, 119-140, 1975.

Bilek, S. L. and T. Lay, Rigidity variations with depth along interpolate megathrust faults in subduction zones, Nature, 400, 443-446, 1999.

Cisternas, M., B. F. Atwater, F. Torrejon, Y. Sawai, G. Machuca, M. Lagos, A. Eipert, C. Youlton, I. Salgado, T. Kamataki, M. Shishikura, C. P. Rajendran, J. K. Malik, Y. Rizal, and M. Husni, Predecessors of the giant 1960 Chile earthquake, Nature, 437, doi:10.1038/nature03943, 2005.

Comte, D. and S. Beck, The 2010 Chile earthquake-Variations in the rupture mode, in Giant Earthquakes and Their Tsunamis, AGU Chapman Conference, 56pp, USGS, Valparaiso, 2010.

Doser, D. I., A. M. Veileux, C. Flores, and W. A. Brown, Changes in seismic-moment rates along the rupture zones of the 1964 great Alaska earthquake, Bull. Seismol. Soc. Am., 96, 1545-1550, 2006.

Engdahl, E. R., R. van der Hilst, and R. Buland, Global teleseismic earthquake relocation with improved travel times and procedures for depth determination, Bull. Seismol. Soc. Am., 88, 722-743, 1998.

Freymueller, J. T., H. Woodard, S. C. Cohen, R. Cross, J. Elliot, C. F. Larson, S. Hreinsdottir, and C. Zweck, Active deformation process in Alaska, based on 15 years of GPS measurements, in Active Tectonics and Seismic Potential in Alaska, edited by J. T. Freymueller, P. T. Haeussler, R. L. Wesson, and G. Ekstrom, 431 pp., Geophysical Monograph Series, AGU, 179, Washington D.C., 2008.

Heki, K., S. Miyazaki, and Y. Tamura, Silent fault slip following an interpolate thrust earthquake at the Japan trench, Nature, 386, 595-597, 1997.

Ide, S., A. Baltay, and G. C. Beroza, Shallow dynamic overshoot and energetic deep rupture in the $2011 \mathrm{Mw} 9.0$ Tohoku-oki earthquake, Science Mag., 332, 1426-1429, 2011.

Johnson, J. M., K. Satake, S. R. Holdahl, and J. Sauber, The 1964 Prince William Sound earthquake: Joint Inversion of tsunami and geodetic data, J. Geophys. Res., 101, 523-532, 1996.

Kanamori, H., The Alaska earthquake of 1964: Radiation of long-period surface waves and source mechanism, J. Geophys. Res., 75, 5029-5040, 1970.

Kanamori, H., Mechanism of tsunami earthquakes, Phys. Earth Planet. Inter., 6, 346-359, 1972.

Kanamori, H., Seismic and aseismic slip along subduction zones and their tectonic implications, in Island Arcs, Deep Sea Trenches and Back-arc Basins, edited by M. Talwani and W. C. Pitman III, 470 pp., AGU, Washington D.C., 1977.

Kanamori, H. and J .J. Cipar, Focal process of the great Chilean earthquake May 22, 1960, Phys. Earth Planet. Inter., 9, 128-136, 1974.

Kanamori, H., M. Miyazawa, and J. Mori, Investigation of the earthquake off Miyagi prefecture with historical seismograms, Earth Planets Space, 58, 1533-1541, 2006.

Kawasaki, I., Y. Asai, and Y. Tamura, Space-time distribution of interpolate moment release inducing slow earthquakes and the seismo-geodetic coupling in the Sanriku-oki region along the Japan trench, Tectono- physics, 330, 267-283, 2001.

Kelleher, J. and J. Savino, Distribution of seismicity before large strike-slip and thrust-type earthquakes, J. Geophys. Res., 80, 260-271, 1975.

Koketsu, K., Y. Yokota, N. Nishimura, Y. Yagi, S. Miyazaki, K. Satake, Y. Fujii, H. Miyake, S. Sakai, Y. Yamanaka, and T. Okada, A unified source model for the 2011 Tohoku earthquake, Earth Planet. Sci. Lett., 310, 480-487, 2011.

Lay, T., H. Kanamori, and L. Ruff, The asperity model and the nature of large subduction zone earthquakes, Earthq. Predict. Res., 1, 3-71, 1982.

Lay, T., H. Kanamori, C. J. Ammon, M. Nettles, S. N. Ward, R. C. Aster, S. L. Beck, S. L. Bilek, M. R. Brudzinski, R. Butler, H. R. DeShon, G. Ekstrom, K. Satake, and S. Sipkin, The great Sumatra-Andaman earthquake of 26 December 2004, Science, 308, 1127-1133, 2005.

Maeda, T., T. Furumura, S. Sakai, and M. Shinohara, Significant tsunami observed at ocean-bottom pressure gauges during the 2011 off the Pacific coast of Tohoku Earthquake, Earth Planets Space, 63, 803-808, 2011.

Marlow, M. S., A. K. Cooper, S. V. Dadisman, E. L. Geist, and P. R. Carlson, Bowers swell: evidence for a zone of compressive deformation concentric with Bowers ridge, Bering Sea, Mar. Petrol. Geol., 7, 398408, 1990.

Maruyama, S., Pacific-type orogeny revisited: Miyamushiro-type orogeny produced, Island Arc, 6, 91-120, 1997.

McCaffrey, R., Oblique plate convergence, slip vectors and forearc deformation, J. Geophys. Res., 97, 8905-8915, 1992.

Moreno, M., M. Rosenau, and O. Oncken, 2010 Maule earthquake slip correlates with pre-seismic locking of Andean subduction zone, Nature, 467, 198-202, 2010.

Neprochnov, Y. P., V. V. Sedov, L. R. Merklin, V. P. Zinkevich, O. V. Levchenko, B. V. Baranov, and G. B. Rudnik, Tectonics of the Shirshov ridge, Bering sea, Geotectonics, 19, 194-206, 1985.

Obara, K., Nonvolcanic deep tremor associated with subduction in southwest Japan, Science, 296, 1679-1681, 2002.

Obara, K., Inhomogeneous distribution of deep slow earthquake activity along the strike of the subducting Philippine Sea Plate, Gondwana Res., 16, 512-526, doi:10.1016/j.gr.2009.04.011, 2009.

Ozawa, S., T. Nishimura, H. Suito, T. Kobayashi, M. Tobita, and T. Imakiire, Coseismic and postseismic slip of the 2011 magnitude-9 Tohoku-oki earthquake, Nature, 475, 373-377, 2011.

Ruff, L. and H. Kanamori, The rupture process and asperity distribution of three great earthquakes from long-period diffracted P-waves, Phys. Earth Planet. Inter., 31, 202-230, 1983.

Shao, G., X. Li, C. Ji, and T. Maeda, Focal mechanism and slip history of the $2011 M_{\mathrm{w}} 9.1$ off the Pacific coast of Tohoku Earthquake, constrained with teleseismic body and surface waves, Earth Planets Space, 63, 559564, 2011.

Stauder, W., Mechanism of the Rat Island earthquake sequence of February 4, 1965, with relation to island arcs and sea floor spreading, J. Geophys. Res., 73, 3847-3858, 1968.

Stein, S. and E. A. Okal, Ultralong period seismic study of the December 2004 Indian ocean earthquake and implication for regional tectonics and the subduction process, Bull. Seismol. Soc. Am., 97, S279-S295, 2007.

Stein, S. and G. F. Sella, Plate boundary zones: Concept and approaches, in Plate Boundary Zones, edited by S. Stein and J. Freymueller, AGU Geodynamics Series, 30, 425 pp., AGU, Washington D.C., 2002.

Suwa, Y., S. Miura, A. Hasegawa, T. Sato, and K. Tachibana, Interplate coupling beneath NE Japan inferred from three-dimensional displacement field, J. Geophys. Res., 111, B04402, doi:10.1029/2004JB003203, 2006.

Tanioka, Y. and K. Satake, Fault parameters of the 1896 Sanriku tsunami earthquake estimated from tsunami numerical modeling, Geophys. Res. Lett., 23, 1549-1552, 1996.

Tsuru, T., J. O. Park, S. Miura, S. Kodaira, Y. Kido, and T. Hayashi, Alongarc structural variation of the plate boundary at the Japan Trench margin: Implication of interpolate coupling, J. Geophys. Res., 107(B12), 2357, doi:10.1029/2001JB001664, 2002.

Usami, T., Catalogue of Disastrous Earthquakes in Japan from 416 to 1995, 493 pp., Tokyo Univ. Press, Tokyo, 1996 (in Japanese).

Utsu, T., Seismology, third edition, 376 pp., Kyoritsu Pub., Tokyo, 2001 (in Japanese).

Uyeda, S., Subduction zones: An introduction to comparative subductology, Tectonophysics, 81, 133-159, 1982.

Uyeda, S. and H. Kanamori, Back-arc opening and the mode of subduction, J. Geophys. Res., 84, 1049-1061, 1979.

Wu, F. T. and H. Kanamori, Source mechanism of February 4, 1965, Rat Island earthquake, J. Geophys. Res., 78, 6082-6092, 1973. 
Wyss, M. and J. N. Brune, The Alaska earthquake of 28 March 1964: A complex multiple rupture, Bull. Seismol. Soc. Am., 57, 1017-1023, 1967.

Yomogida, K., K. Yoshizawa, J. Koyama, and M. Tsuzuki, Along-dip segmentation of the 2011 off the Pacific coast of Tohoku Earthquake and comparison with other megathrust earthquakes, Earth Planets Space, 63, 697-701, 2011.

Yoshida, Y., H. Ueno, D. Muto, and S. Aoki, Source process of the 2011 off the Pacific coast of Tohoku Earthquake with the combination of teleseismic and strong motion data, Earth Planets Space, 63, 565-569, 2011.

J. Koyama (e-mail: koyama@mail.sci.hokudai.ac.jp), K. Yoshizawa, K Yomogida, and M. Tsuzuki 